\title{
Chemical composition and insecticidal activity of plant essential oils from Benin against Anopheles gambiae (Giles)
}

Annick D Bossou ${ }^{1,2}$, Sven Mangelinckx ${ }^{2 *}$, Hounnankpon Yedomonhan ${ }^{3}$, Pelagie M Boko ${ }^{4}$, Martin C Akogbeto $^{4}$, Norbert De Kimpe ${ }^{2}$, Félicien Avlessi ${ }^{1}$ and Dominique C K Sohounhloue ${ }^{1 *}$

\begin{abstract}
Background: Insecticide resistance in sub-Saharan Africa and especially in Benin is a major public health issue hindering the control of the malaria vectors. Each Anopheles species has developed a resistance to one or several classes of the insecticides currently in use in the field. Therefore, it is urgent to find alternative compounds to conquer the vector. In this study, the efficacies of essential oils of nine plant species, which are traditionally used to avoid mosquito bites in Benin, were investigated.

Methods: Essential oils of nine plant species were extracted by hydrodistillation, and their chemical compositions were identified by GC-MS. These oils were tested on susceptible "kisumu" and resistant "Iadji-Cotonou" strains of Anopheles gambiae, following WHO test procedures for insecticide resistance monitoring in malaria vector mosquitoes.

Results: Different chemical compositions were obtained from the essential oils of the plant species. The major constituents identified were as follows: neral and geranial for Cymbopogon citratus, Z-carveol, E-p-mentha-1(7),8-dien-2-ol and E-p-mentha-2,8-dienol for Cymbopogon giganteus, piperitone for Cymbopogon schoenanthus, citronellal and citronellol for Eucalyptus citriodora, p-cymene, caryophyllene oxide and spathulenol for Eucalyptus tereticornis, 3-tetradecanone for Cochlospermum tinctorium and Cochlospermum planchonii, methyl salicylate for Securidaca longepedunculata and ascaridole for Chenopodium ambrosioides. The diagnostic dose was $0.77 \%$ for C. citratus, 2.80\% for E. tereticornis, 3.37\% for E. citriodora, 4.26\% for C. ambrosioides, 5.48\% for C. schoenanthus and 7.36\% for C. giganteus. The highest diagnostic doses were obtained with S. longepedunculata (9.84\%), C. tinctorium (11.56\%) and C. planchonii (15.22\%), compared to permethrin 0.75\%. A. gambiae cotonou, which is resistant to pyrethroids, showed significant tolerance to essential oils from C. tinctorium and S. Iongepedunculata as expected but was highly susceptible to all the other essential oils at the diagnostic dose.

Conclusions: C. citratus, E. tereticornis, E. citriodora, C. ambrosioides and C. schoenanthus are potential promising plant sources for alternative compounds to pyrethroids, for the control of the Anopheles malaria vector in Benin. The efficacy of their essential oils is possibly based on their chemical compositions in which major and/or minor compounds have reported insecticidal activities on various pests and disease vectors such as Anopheles.
\end{abstract}

Keywords: Malaria, A. gambiae, Essential oils, Diagnostic dose, Knock-down times, Insecticide, Benin

\footnotetext{
* Correspondence: sven.mangelinckx@ugent.be; csohoun@gmail.com

${ }^{2}$ Department of Sustainable Organic Chemistry and Technology, Faculty of Bioscience Engineering, Ghent University, Coupure links 653, Ghent B-9000, Belgium

'Laboratoire d'Etude et de Recherche en Chimie Appliquée, Ecole

Polytechnique d'Abomey-Calavi, Université d'Abomey-Calavi, Cotonou 01 BP 2009, Bénin
}

\section{Biomed Central}

(c) 2013 Bossou et al.; licensee BioMed Central Ltd. This is an Open Access article distributed under the terms of the Creative Commons Attribution License (http://creativecommons.org/licenses/by/2.0), which permits unrestricted use, distribution, and reproduction in any medium, provided the original work is properly cited. The Creative Commons Public Domain Dedication waiver (http://creativecommons.org/publicdomain/zero/1.0/) applies to the data made available in this article, unless otherwise stated. 


\section{Background}

Malaria is a life-threatening disease affecting 3.3 billion people worldwide with $80 \%$ of cases and $90 \%$ of deaths occurring in sub-Saharan Africa (SSA). Of those affected, children under the age of five and pregnant women are the most vulnerable [1]. The key factor for the reduction of human mortality is their protection against the malaria parasite vectors, the Anopheles mosquito, by the use of long-lasting insecticidal nets (LLIN) and application of indoor residual spraying (IRS) as recommended by the WHO [1]. Pyrethroids are the only insecticides recommended by WHO for the treatment of bednets [1] while in West Africa, Anopheles gambiae Giles is the major vector of malaria [2]. This mosquito species is now subjected to selection pressure, and has become resistant to dichlorodiphenyltrichloroethane (DDT) and pyrethroids because of the use of these insecticides both for agricultural and public health purposes [2,3]. During the last decade, the emergence of resistance to synthetic insecticides in Anopheles populations has been widely described in many African countries such as Benin [4-10], Ivory Coast [2,11], Niger [12], Burkina Faso [3,13,14], Mali [15], Nigeria [16], Kenya [17], Cameroun [18-20], Zanzibar [21], Uganda [22], Equatorial Guinea [23], and Ghana [24]. Because of the widespread occurrence of this resistance, there is a reduction of the efficacy of synthetic insecticides used in the field. Therefore, it is pertinent to explore the pesticidal activity of natural products [25] such as essential oils. Indeed the use of essential oils has been recognized as a potential alternative in the control of vectors of mosquito-borne diseases [26-30] such as A. gambiae. A lot of research on the pesticidal activities of essential oils has been conducted and has proven that essential oils could be considered as potent bioactive compounds against various pests and mosquitoes [28,31-34].

The objective of the current study was to investigate the chemical composition and the insecticidal activities of essential oils of nine aromatic plants traditionally used in Benin as a natural method of protection against $A$. gambiae, in order to confirm the traditional knowledge of Benin's population and to find new valuable sources of active molecules against this malaria vector. Indeed these plant species have been reported to possess repellent and insecticidal activities against various mosquitoes, stored product beetles and other pests such as Anopheles species [30,35], Culex quinquefasciatus [36], Callosobruchus species [37,38], Sitophilus species [39,40] and Tribolium castaneum [41]. These plants include Chenopodium ambrosioides L. (Amaranthaceae), Securidaca longepedunculata Fresen. (Polygalaceae), Cochlospermum planchonii Hook. f. Ex Planch. (Bixaceae), Cochlospermum tinctorium A. Rich. (Bixaceae), Eucalyptus tereticornis Sm. (Myrtaceae), Eucalyptus citriodora Hook. (Myrtaceae),
Cymbopogon citratus (DC.) Stapf (Poaceae), Cymbopogon schoenanthus (L.) Spreng. (Poaceae) and Cymbopogon giganteus Chiov. (Poaceae).

For this purpose, the standard WHO susceptibility test has been used with various concentrations of essential oils under laboratory conditions [42].

\section{Methods}

\section{Plant material}

Nine plant species belonging to five botanical families were collected in several regions of Benin. Collected plant material was dried, free from light, at room temperature. All these plants have been the subject of classification and botanic description at the National Herbarium of the University of Abomey-Calavi, Benin [43]. Locations of collection, organs extracted and nature of soil are summarized in Table 1.

\section{Essential oils}

Essential oils from all plants were extracted by hydrodistillation using a Clevenger-type apparatus for two to four hours until essential oils were extracted completely from the organs. The extracted oils were dried over anhydrous magnesium sulfate and stored at $4^{\circ} \mathrm{C}$, away from UV rays, before use. Each essential oil was diluted tenfold with diethyl ether. One milliliter of each diluted solution was charged into a sampler flask for GC-MS analysis.

\section{Chemical analyses of essential oils by gas chromatography coupled with mass spectrometry}

The GC-MS analysis of the essential oils was performed on an Agilent 6890 GC Plus automatic sampler system, coupled to a quadruple mass spectrometer 5973 MSD (Agilent Technologies, Diegem, Belgium) and equipped with a capillary HP-5MS column fused with silica (length: $30 \mathrm{~m}$; diameter: $0.25 \mathrm{~mm}$, film thickness: 0.25 microns) in the split mode 1:100. The oven temperature was programmed at $60^{\circ} \mathrm{C}$ for $3 \mathrm{~min}$ and to $350^{\circ} \mathrm{C}$ at a rate of $5^{\circ} \mathrm{C} / \mathrm{min}$. The injector was kept at $250^{\circ} \mathrm{C}$ programmed with a rate of $10^{\circ} \mathrm{C} / \mathrm{s}$. Helium was used as carrier gas at a flow rate of $1 \mathrm{ml} / \mathrm{min}$. All analyses were performed at constant flow. The mass detector conditions were: transfer line temperature $260^{\circ} \mathrm{C}$; ionization mode electron impact: $70 \mathrm{eV}$. The identification of sample compounds was carried out in single runs. The Kovats retention indices were calculated for all volatile constituents using a series of $n$-alkanes $C_{7}-C_{17}$ [44]. Quantification of each compound was performed using percentage peak area calculations. The identification of oil volatile compounds was done by comparing their retention indices with those of reference compounds in the literature and confirmed by GC-MS by comparison of their mass spectra with those of reference compounds [44-47]. The relative concentration of each 
Table 1 Locations, soils and organs extracted from selected plants species

\begin{tabular}{|c|c|c|c|c|c|c|c|c|c|}
\hline Plants species & $\begin{array}{l}\text { Cymbopogon } \\
\text { citratus }\end{array}$ & $\begin{array}{l}\text { Cymbopogon } \\
\text { giganteus }\end{array}$ & $\begin{array}{l}\text { Cymbopogon } \\
\text { schoenanthus }\end{array}$ & $\begin{array}{l}\text { Cochlospermum } \\
\text { planchonii }\end{array}$ & $\begin{array}{l}\text { Cochlospermum } \\
\text { tinctorium }\end{array}$ & $\begin{array}{l}\text { Eucalyptus } \\
\text { citriodora }\end{array}$ & $\begin{array}{l}\text { Eucalyptus } \\
\text { tereticornis }\end{array}$ & $\begin{array}{l}\text { Chenopodium } \\
\text { ambrosioides }\end{array}$ & $\begin{array}{l}\text { Securidaca } \\
\text { longepedunculata }\end{array}$ \\
\hline Locations & Cotonou & Koudo & Nalohou 2 & Mount Kassa & Mount Kassa & Abomey Calavi & Abomey Calavi & Savalou & Savalou \\
\hline Soils & Sandy & Ferralitic & Gravelly ferruginous & Ferruginous & Ferruginous & Ferralitic & Ferralitic & Ferruginous & Ferruginous \\
\hline Organs & Leaves & Leafy stems & Leafy stems & Roots & Roots & Leaves & Leaves & Leafy stems & Root bark \\
\hline Certification numbers & AA6463/HNB & AA6464/HNB & AA6465/HNB & AA6466/HNB & AA6467/HNB & AA6468/HNB & AA6469/HNB & AA6470/HNB & AA6471/HNB \\
\hline
\end{tabular}


compound in the essential oil was quantified according to the peak area integrated by the analysis program (Chemstation data analysis).

\section{Mosquito collection}

Larvae of the resistant strain of $A$. gambiae were collected three times a week, from March 2012 to June 2012, from the natural breeding site in "Ladji" in Cotonou. Ladji is a neighborhood of the outskirts of Cotonou, the capital of Benin. Larvae were brought and reared in the insectary of the Cotonou Research Center of Entomology (CREC). Larvae were fed with honey juice and the adults were placed in cages and fed in the same way. Emerging adult female mosquitoes of the resistant strain were used to carry out the susceptibility tests, whereas a susceptible strain of A. gambiae "Kisumu" originating from Kenya and maintained at the insectary, were used as a reference.

\section{Bioassay on adult mosquitoes}

Susceptibility tests were carried out using WHO insecticide susceptibility test-kits and standard procedures [42]. Four replicates of batches of 20-25 unfed females, aged 2-5 days old were exposed to filter papers (Whatman $\left.\mathrm{N}^{\circ} 1\right) 12 \mathrm{~cm} \times 15 \mathrm{~cm}$, impregnated with $2 \mathrm{ml}$ of various doses of the essential oil, diluted in acetone. The susceptible strain A. gambiae "Kisumu" was used as reference to determine the diagnostic doses. The filter papers of the control holding tubes were impregnated with acetone only. Tests were carried out at $25^{\circ} \mathrm{C}\left( \pm 2^{\circ} \mathrm{C}\right)$ and $70-80 \%$ relative humidity. Six doses were tested for each essential oil: $0.25 \%(\mathrm{w} / \mathrm{v}), 0.50 \%(\mathrm{w} / \mathrm{v}), 1 \%(\mathrm{w} / \mathrm{v}), 2 \%$ $(\mathrm{w} / \mathrm{v}), 4 \%(\mathrm{w} / \mathrm{v})$ and $8 \%(\mathrm{w} / \mathrm{v})$. The number of mosquitoes knocked down was recorded every $5 \mathrm{~min}$. Permethrin $0.75 \%$ was used as reference insecticide. Permethrin impregnated papers were obtained from the WHO reference center of "the Vector Control Research Unit of The University Sains Malaysia”. After the exposure time, mosquitoes were transferred to holding tubes and were fed with $10 \%$ honey juice for 24 hours. Subsequently the mortality was recorded. Data were plotted to determine the diagnostic doses to which the resistant strain from Ladji was exposed.

\section{Data analysis for bioassay}

Times at which $50 \%$ or $95 \%$ of mosquitoes fell down on their back or on their side, i.e. knockdown time $\left(\mathrm{KDT}_{50}\right.$ and $\mathrm{KDT}_{95}$ ) was calculated by means of the log timeprobit using SPSS 17.0 software. The relation between the KDT, the mortality and the doses were assessed by probit regression. The diagnostic concentration which is the double of the minimum concentration at which $100 \%$ of the susceptible strain died [48] was also taken into account. All the results obtained for KDT $\left(\mathrm{KDT}_{50}\right.$ and $\mathrm{KDT}_{95}$ ) and lethal doses $\left(\mathrm{LC}_{50}\right.$ and $\left.\mathrm{LC}_{99}\right)$, were expressed with 95\% confidence limits.

\section{Results and discussion}

\section{Chemical composition of essential oils}

Chemical compositions and essential oil yields, expressed as oil wt./wt. of dried organ extracted, showed a large variation (Tables 2, 3, 4, 5 and 6). These yields varied from $0.2 \%$ for Cochlospermum species to $4.6 \%$ for E. citriodora.

\section{C. citratus}

The oil yield of C. citratus was $1.7 \%(w / w)$. This value is higher than the one obtained with $C$. citratus (1.3\%) collected in northern Brazil [49]. Essential oil of C. citratus was characterized by myrcene (12.4\%), neral (33.1\%) and geranial (44.3\%). This result corroborates with previous results [49], which showed that the aerial part of $C$. citratus contains myrcene (10.7\%), neral (30.8\%) and geranial (53.9\%). Furthermore, myrcene, neral and geranial were also the main compounds identified in C. citratus characterized in Burkina Faso, Brazil and Portugal [50-52].

\section{C. giganteus}

The oil yield of C. giganteus was $1.4 \%(\mathrm{w} / \mathrm{w})$ and the main constituents of its essential oil were limonene $(9.6 \%)$ and a set of monoterpene alcohols: $E$-p-mentha1(7),8-dien-2-ol (19.6\%), E-p-mentha-2,8-dienol (19.3\%), $Z$-p-mentha-2,8-dienol (10.2\%), Z-p-mentha-1(7),8-dien2-ol (2.1\%), $Z$-carveol (17.0\%) and $E$-carveol (6.0\%) together with $p$-menth-6-en-2,3-diol (3.2\%) and carvone (3.2\%).

This composition is similar to that of $C$. giganteus from Burkina Faso which was characterized by $E$ - $p$-mentha1(7),8-dien-2-ol, E-p-mentha-2,8-dienol, $Z$ - $p$-mentha2,8-dienol and $Z$-p-mentha-1(7),8-dien-2-ol [52] and from many West and Central African countries [28,53-55].

\section{C. schoenanthus}

The yield of C. schoenanthus essential oil was $2.6 \%(\mathrm{w} / \mathrm{w})$. This result is similar to Ketoh et al. [56]. In the current work the major constituents were $\delta$-2-carene $(15.5 \%)$ and piperitone (58.9\%); these results are consistent with the results obtained by Koba et al. and Ketoh et al. [38,56,57].

\section{E. citriodora}

Essential oil from E. citriodora was extracted with a yield of $4.6 \%$. The main compounds detected by GC-MS were citronellal (52.8\%), citronellol (20.0\%), citronellyl acetate (9.0\%) and neo-isopulegol (7.8\%). Components like citronellal, citronellol and isopulegol were also detected in E. citriodora essential oil analyzed in Colombia [27,41]. 
Table 2 Chemical composition and oil yields of Cymbopogon species

\begin{tabular}{|c|c|c|c|c|c|c|}
\hline \multirow[t]{2}{*}{$\mathrm{KI}_{\exp }^{\mathrm{a}}$} & \multirow[t]{2}{*}{$\mathrm{KI}_{\text {lit }}^{\mathrm{b}}$} & \multirow[t]{2}{*}{$I^{c}$} & \multirow[t]{2}{*}{ Compounds $^{d}$} & \multirow{2}{*}{$\begin{array}{l}\text { Cymbopogon } \\
\text { citratus } \\
\%\end{array}$} & \multirow{2}{*}{$\begin{array}{l}\text { Cymbopogon } \\
\text { giganteus } \\
\%\end{array}$} & \multirow{2}{*}{$\begin{array}{l}\text { Cymbopogon } \\
\text { schoenanthus } \\
\%\end{array}$} \\
\hline & & & & & & \\
\hline 978 & 974 & $\mathrm{MS}, \mathrm{RI}$ & Sulcatone & 0.5 & & \\
\hline 982 & 988 & MS, RI & Myrcene & 12.4 & & \\
\hline 984 & 988 & MS, RI & 2,3-Dehydro-1,8-cineole & & 0.1 & 0.1 \\
\hline 995 & 1001 & MS, RI & $\delta$-2-Carene & & 0.1 & 15.5 \\
\hline 998 & 1002 & MS, RI & a-Phellandrene & & & 0.2 \\
\hline 1009 & 1014 & MS, RI & a-Terpinene & & & 0.2 \\
\hline 1017 & 1020 & MS, RI & p-Cymene & & 0.5 & 0.1 \\
\hline 1020 & 1024 & MS, RI & Limonene & & 9.6 & 3.6 \\
\hline 1029 & 1032 & $\mathrm{MS}, \mathrm{RI}$ & Z- $\beta$-Ocimene & 0.3 & & 0.1 \\
\hline 1039 & 1044 & $\mathrm{MS}, \mathrm{RI}$ & E- $\beta$-Ocimene & 0.2 & & 0.1 \\
\hline 1081 & 1083 & MS, RI & L-Fenchone & & & 0.2 \\
\hline 1082 & 1082 & MS, RI & m-Cymenene & & 0.2 & \\
\hline 1085 & 1090 & MS, RI & 6,7-Epoxymyrcene & 0.2 & & \\
\hline 1093 & 1095 & MS, RI & Linalool & 1.1 & & \\
\hline 1114 & 1118 & MS, RI & Z-p-menth-2-en-1-ol & & & 1.4 \\
\hline 1116 & 1119 & MS, RI & E-p-Mentha-2,8-dienol & & 19.3 & \\
\hline 1129 & 1133 & MS, RI & Z-p-Mentha-2,8-dienol & & 10.2 & \\
\hline 1132 & 1136 & MS, RI & E-p-menth-2-en-1-ol & & & 0.7 \\
\hline 1138 & 1144 & MS, RI & Neo-Isopulegol & & 0.1 & \\
\hline 1145 & 1148 & MS, RI & Citronellal & 0.1 & 0.7 & \\
\hline 1148 & & MS & 4-Isopropenylcyclohexanone & & 0.4 & \\
\hline 1160 & 1166 & MS, RI & p-mentha-1,5-dien-8-ol & & & 0.1 \\
\hline 1168 & 1173 & MS, RI & Rose furan epoxide & 0.2 & & \\
\hline 1180 & 1179 & MS, RI & p-Cymen-8-ol & & & 0.1 \\
\hline 1183 & 1186 & MS, RI & a-Terpineol & & & 1.5 \\
\hline 1183 & 1187 & MS, RI & E-p-Mentha-1(7),8-dien-2-ol & & 19.6 & \\
\hline 1188 & 1195 & MS, RI & Z-Piperitol & & & 0.3 \\
\hline 1194 & & MS & p-Menth-6-en-2,3-diol & & 3.2 & \\
\hline 1201 & 1209 & MS, RI & E-Piperitol & & & 0.2 \\
\hline 1212 & 1215 & MS, RI & E-Carveol & & 6.0 & \\
\hline 1216 & 1224 & $M S, R I$ & 2,3-Epoxyneral & 0.1 & & \\
\hline 1224 & 1226 & MS, RI & Z-Carveol & & 17.0 & \\
\hline 1225 & 1227 & MS, RI & Z-p-Mentha-1(7),8-dien-2-ol & & 2.1 & \\
\hline 1237 & 1235 & $M S, R I$ & Neral & 33.1 & & \\
\hline 1237 & 1239 & MS, RI & Carvone & & 3.2 & \\
\hline 1253 & 1249 & MS, RI & Piperitone & & 0.1 & 58.9 \\
\hline 1257 & 1249 & MS, RI & Geraniol & 1.0 & & \\
\hline 1266 & 1269 & MS, RI & Perilla aldehyde & & 0.8 & \\
\hline 1268 & 1264 & $M S, R I$ & Geranial & 44.3 & & \\
\hline 1286 & 1293 & MS, RI & 2-Undecanone & 0.1 & & \\
\hline 1351 & 1359 & MS, RI & Geranic acid & 0.1 & & \\
\hline 1376 & 1379 & MS, RI & Geranyl acetate & 0.8 & & \\
\hline
\end{tabular}


Table 2 Chemical composition and oil yields of Cymbopogon species (Continued)

\begin{tabular}{|c|c|c|c|c|c|c|}
\hline 1382 & 1389 & $\mathrm{MS}, \mathrm{RI}$ & $\beta$-Elemene & & & 0.4 \\
\hline 1408 & 1417 & MS, RI & E-Caryophyllene & 0.1 & & 1.1 \\
\hline 1421 & 1431 & $M S, R I$ & $\beta$-Gurjunene & & & 0.1 \\
\hline 1443 & 1452 & $M S, R I$ & a-Humulene & & & 0.1 \\
\hline 1486 & 1495 & $\mathrm{MS}, \mathrm{RI}$ & 2-Tridecanone & 0.1 & & \\
\hline 1490 & 1500 & $M S, R I$ & a-Muurolene & & & 0.1 \\
\hline 1503 & 1513 & $M S, R I$ & $\gamma$-Cadinene & & & 0.1 \\
\hline 1513 & 1522 & MS, RI & $\delta$-Cadinene & & & 0.4 \\
\hline 1540 & 1546 & MS, RI & Elemol & & & 5.3 \\
\hline 1571 & 1582 & $\mathrm{MS}, \mathrm{RI}$ & Caryophyllene oxide & 0.1 & 0.1 & \\
\hline 1595 & 1607 & $\mathrm{MS}, \mathrm{RI}$ & 5-Epi-7-epi-a-eudesmol & & & 0.3 \\
\hline 1609 & 1622 & $M S, R I$ & 10-Epi-ү-eudesmol & & & 0.2 \\
\hline 1609 & 1615 & MS, RI & Selina-6-en-4-ol & 0.4 & & \\
\hline 1636 & 1640 & $\mathrm{MS}, \mathrm{RI}$ & Phenyl ethyl hexanoate & & 0.1 & \\
\hline 1623 & 1630 & $\mathrm{MS}, \mathrm{RI}$ & $\gamma$-Eudesmol & & & 1.1 \\
\hline 1626 & 1629 & MS, RI & Eremoligenol & & & 1.9 \\
\hline 1634 & 1640 & $M S, R I$ & Hinesol & & & 0.7 \\
\hline 1643 & 1649 & $\mathrm{MS}, \mathrm{RI}$ & $\beta$-Eudesmol & & & 1.2 \\
\hline \multirow[t]{3}{*}{1646} & 1652 & $\mathrm{MS}, \mathrm{RI}$ & a-Eudesmol & & & 2.1 \\
\hline & & & Yields & 1.7 & 1.4 & 2.6 \\
\hline & & & Total identified & 95.2 & 93.4 & 98.4 \\
\hline
\end{tabular}

${ }^{\mathrm{a}} \mathrm{Kl} \mathrm{exp}_{\text {ex }}=$ retention indices are determined using n-alkanes $\left(\mathrm{C}_{7}-\mathrm{C}_{17}\right)$.

${ }^{\mathrm{b}} \mathrm{KI}_{\text {lit }}=$ retention indices of reference compounds from literature.

$\mathrm{CID}=$ Identification methods; $\mathrm{MS}=$ comparison of the mass spectrum with those of the computer mass libraries, and Adams (2007); RI = comparison of calculated $\mathrm{RI}$ with those reported in the literature.

${ }^{\mathrm{d}}$ Compounds are listed in order of their retention time; the names and the percentages of main compounds are indicated in bold.

\section{E. tereticornis}

E. tereticornis essential oil was extracted with a yield of $1.0 \%$. This yield is lower than the one obtained from leaves of E. tereticornis (3.4\%) isolated in Nigeria [58]. In our study, this oil was characterized by the presence of $p$-cymene (16.7\%), cryptone (11.4\%), spathulenol (13.5\%), caryophyllene oxide (14.2\%). Furthermore, compounds such as 4-terpineol (4.4\%), phellandral (4.2\%), cumin aldehyde (3.1\%), $\beta$-phellandrene (2.9\%), 1,8-cineole (2.2\%) and humulene epoxide II (2.2\%) were detected in significant amounts. $p$-Cymene, $\beta$-phellandrene, 1,8-cineole, 4-terpineol, cryptone and spathulenol were also identified in the oil of E. tereticornis analyzed in Benin, by Alitonou et al. [59] but in different amounts. Other differences were that it did not contain cumin aldehyde, humulene epoxide II and phellandral, whereas $\alpha$-phellandrene, bicyclogermacrene and $\alpha-, \beta$ or $\gamma$-isomers of eudesmol were detected. The presence of these main compounds was also noticed in the oil extracted in Argentina [60,61]. In contrast, the major constituents of the fresh leaf oil analyzed in India and Ethiopia were $\alpha$-pinene and 1,8-cineole [62,63], whereas the main compounds in the essential oil from Nigeria were $\alpha$ - and $\beta$-pinene [58], the one from Cuba were 1,8-cineole and $p$-cymene [64], and the one from Algeria contained $\alpha$-pinene, 1,8-cineole, $\beta$-ocimene, alloaromadendrene and 4-terpineol [65].

\section{C. tinctorium}

Essential oil yield of C. tinctorium was $0.2 \%(\mathrm{w} / \mathrm{w})$ which is higher than the one obtained in Burkina Faso (0.10\%) by Benoit-Vical et al. [66]. The essential oil extracted from $C$. tinctorium in the current study is dominated by 3 -tetradecanone (48.3\%). 3-hexadecanone (7.4\%), 2-tridecanone $(3.4 \%)$, cyclododecanone $(7.8 \%)$, dodecyl acetate $(2.0 \%)$, methyl tetradecanoate $(2.3 \%)$ and 1 -tetradecanol acetate (4.3\%). This chemical composition is similar to the result obtained by Benoit-Vical et al. [66], in the tubercle essential oil which contained 3-tetradecanone (64.6\%), 3-hexadecanone (5.6\%), dodecyl acetate $(4.6 \%)$, in addition to 3-hexadecenone $(3.4 \%)$ and tetradecyl acetate $(11.7 \%)$.

\section{C. planchonii}

The essential oil of $C$. planchonii was extracted with a yield of $0.20 \%(\mathrm{w} / \mathrm{w})$ lower than in the tubercle from Burkina Faso $(0.30 \%)$ [66]. In the current study the composition of 
Table 3 Chemical composition and oil yields of Eucalyptus species

\begin{tabular}{|c|c|c|c|c|c|}
\hline$\overline{\mathrm{KI}_{\exp }{ }^{\mathrm{a}}}$ & $\mathrm{KI}_{\mathrm{lit}}^{\mathrm{b}}$ & $\mathrm{ID}^{c}$ & Compounds $^{d}$ & $\begin{array}{l}\text { E. citriodora } \\
\%\end{array}$ & $\begin{array}{l}\text { E. tereticornis } \\
\%\end{array}$ \\
\hline 918 & 924 & $M S, R I$ & a-Thujene & & 1.7 \\
\hline 925 & 925 & $M S, R I$ & a-Pinene & 0.1 & 0.7 \\
\hline 964 & 969 & $\mathrm{MS}, \mathrm{RI}$ & Sabinene & & 0.5 \\
\hline 968 & 974 & $\mathrm{MS}, \mathrm{RI}$ & $\beta$-Pinene & 0.2 & 0.1 \\
\hline 982 & 988 & MS, RI & Myrcene & 0.1 & 0.3 \\
\hline 998 & 1002 & $M S, R I$ & a-Phellandrene & & 0.5 \\
\hline 1009 & 1014 & $\mathrm{MS}, \mathrm{RI}$ & a-Terpinene & 0.1 & 0.5 \\
\hline 1017 & 1020 & $\mathrm{MS}, \mathrm{RI}$ & $p$-Cymene & 0.1 & 16.7 \\
\hline 1020 & 1024 & $\mathrm{MS}, \mathrm{RI}$ & Limonene & 0.2 & \\
\hline 1021 & 1025 & MS, RI & $\beta$-Phellandrene & & 2.9 \\
\hline 1023 & 1026 & $\mathrm{MS}, \mathrm{RI}$ & 1,8-Cineole (Eucalyptol) & 1.5 & 2.2 \\
\hline 1045 & 1044 & $\mathrm{MS}, \mathrm{RI}$ & 2,6-dimethyl-5-Heptenal & 0.2 & \\
\hline 1050 & 1054 & $M S, R I$ & y-Terpinene & 0.1 & 0.7 \\
\hline 1080 & 1086 & $\mathrm{MS}, \mathrm{RI}$ & Terpinolene & & 0.1 \\
\hline 1081 & 1089 & $M S, R I$ & p-Cymenene & & 0.3 \\
\hline 1093 & 1095 & $\mathrm{MS}, \mathrm{RI}$ & Linalool & 0.4 & 0.1 \\
\hline 1104 & 1106 & $\mathrm{MS}, \mathrm{RI}$ & Z-Rose oxide & 0.1 & \\
\hline 1109 & 1112 & MS, RI & E-Thujone & & 0.2 \\
\hline 1114 & 1118 & $M S, R I$ & Z-p-Menth-2-en-1-ol & & 0.5 \\
\hline 1132 & 1136 & $\mathrm{MS}, \mathrm{RI}$ & E-p-Menth-2-en-1-ol & & 0.4 \\
\hline 1139 & 1144 & $\mathrm{MS}, \mathrm{RI}$ & Neo-Isopulegol & 7.8 & \\
\hline 1150 & 1148 & $M S, R I$ & Citronellal & 52.8 & 0.1 \\
\hline 1150 & 1154 & MS, RI & Sabina ketone & & 0.1 \\
\hline 1152 & 1155 & $M S, R I$ & Iso-Isopulegol & 3.0 & \\
\hline 1166 & 1167 & $\mathrm{MS}, \mathrm{RI}$ & Umbellulone & & 0.1 \\
\hline 1170 & 1174 & $\mathrm{MS}, \mathrm{RI}$ & Terpinen-4-ol & & 4.4 \\
\hline 1181 & 1183 & $M S, R I$ & Cryptone & & 11.4 \\
\hline 1184 & 1186 & $M S, R I$ & a-Terpineol & 0.3 & 0.5 \\
\hline 1200 & 1192 & $M S, R I$ & a-Phellandrene Epoxide & & 0.2 \\
\hline 1223 & 1224 & $\mathrm{MS}, \mathrm{RI}$ & m-Cumenol & & 0.5 \\
\hline 1224 & 1223 & $\mathrm{MS}, \mathrm{Rl}$ & Citronellol & 20.0 & \\
\hline 1232 & 1238 & $M S, R I$ & Cumin aldehyde & & 3.1 \\
\hline 1236 & 1239 & MS, RI & Carvone & & 0.1 \\
\hline 1239 & 1244 & MS, RI & Carvotanacetone & & 0.1 \\
\hline 1246 & 1249 & $\mathrm{MS}, \mathrm{Rl}$ & Piperitone & & 0.2 \\
\hline 1267 & 1273 & MS, RI & p-Menth-1-en-7-al & & 4.2 \\
\hline 1268 & 1274 & $M S, R I$ & Neo-isopulegyl acetate & 0.3 & \\
\hline 1276 & 1283 & $\mathrm{MS}, \mathrm{RI}$ & a-Terpinen-7-al & & 0.3 \\
\hline 1296 & 1298 & $\mathrm{MS}, \mathrm{RI}$ & Carvacrol & & 1.4 \\
\hline 1301 & 1308 & MS, RI & p-Cymen-7-ol & & 0.3 \\
\hline 1326 & 1330 & $M S, R I$ & 3-Oxo-p-menth-1-en-7-al & & 0.2 \\
\hline 1346 & 1350 & $M S, R I$ & Citronellyl acetate & 9.0 & \\
\hline 1382 & 1389 & $M S, R I$ & $\beta$-Elemene & & 0.1 \\
\hline
\end{tabular}


Table 3 Chemical composition and oil yields of Eucalyptus species (Continued)

\begin{tabular}{|c|c|c|c|c|c|}
\hline 1391 & 1392 & $M S, R I$ & Z-Jasmone & 0.2 & \\
\hline 1408 & 1417 & MS, RI & E-Caryophyllene & 0.4 & 0.5 \\
\hline 1443 & 1452 & MS, RI & a-Humulene & & 0.3 \\
\hline 1450 & 1458 & $M S, R I$ & Allo-Aromadendrene & & 0.9 \\
\hline 1485 & 1488 & MS, RI & Bicyclogermacrene & 0.1 & \\
\hline 1513 & 1521 & MS, RI & E-Calamenene & & 0.2 \\
\hline 1568 & 1571 & MS, RI & Spathulenol & 0.1 & 13.5 \\
\hline 1574 & 1582 & MS, RI & Caryophyllene oxide & & 14.2 \\
\hline 1592 & 1590 & MS, RI & Globulol & & 0.6 \\
\hline 1598 & 1600 & $M S, R I$ & Humulene epoxide II & & 2.2 \\
\hline 1631 & 1631 & MS, RI & Isospathulenol & & 1.6 \\
\hline 1643 & 1639 & MS, RI & Caryophylla-4(12),8(13)-dien-5- $\beta$-ol & & 0.9 \\
\hline 1648 & 1652 & MS, RI & a-Cadinol & & 0.3 \\
\hline 1729 & 1733 & $M S, R I$ & Isobicyclogermacrenal & & 0.8 \\
\hline \multirow[t]{3}{*}{1753} & 1759 & $M S, R I$ & Cyclocolorenone & & 0.6 \\
\hline & & & Yields & 4.6 & 1.0 \\
\hline & & & Total identified & 97.1 & 92.3 \\
\hline
\end{tabular}

${ }^{\mathrm{a}} \mathrm{KI}_{\text {exp }}=$ retention indices are determined using $\mathrm{n}$-alkanes $\left(\mathrm{C}_{7}-\mathrm{C}_{17}\right)$.

${ }^{\mathrm{b}} \mathrm{KI}_{\text {lit }}=$ retention indices of reference compounds from literature.

$\mathrm{ID}=$ Identification methods; $\mathrm{MS}=$ comparison of the mass spectrum with those of the computer mass libraries, and Adams (2007); RI = comparison of calculated $\mathrm{RI}$ with those reported in the literature.

${ }^{\mathrm{d}}$ Compounds are listed in order of their retention time; the names and the percentages of main compounds are indicated in bold.

this essential oil was dominated by 3-tetradecanone (24.7\%), ethyl tetradecanoate (11.4\%) and isoamyl dodecanoate $(14.1 \%)$, accompanied by 2 -tridecanone (6.8\%), dodecyl acetate $(4.9 \%), 2$-pentadecanone $(5.7 \%)$, n-tetradecanol (3.0\%), 3-hexadecanone (2.0\%) and 4-octadecanone (2.2\%). In the sample from Burkina Faso, 3-tetradecanone (69.8\%) was the main compound, followed by tetradecyl acetate (14.4\%), dodecyl acetate (4.7\%), 3-hexadecanone (2.5\%) and n-tetradecanol (1.0\%) [66]. The sample characterized by Ouattara et al. [67] was similar to the previous one with major components involving 3-tetradecanone, 3-tetradecenone, dodecyl acetate, tetradecyl acetate, 2 -tridecanone and $\beta$-elemene.

\section{S. longepedunculata}

The essential oil of $S$. longepedunculata was extracted with a yield of $0.7 \%(\mathrm{w} / \mathrm{w})$. This yield is higher than the result obtained (0.30\%-0.52\%) by Alitonou et al. [68] in Benin and Adebayo et al. in Nigeria [69]. The S. longepedunculata essential oil was characterized by only one major constituent, namely methyl salicylate (99.4\%). Indeed Nebie et al. [70] has shown that the essential oil of S. longepedunculata from Burkina Faso contains only one compound which is methyl salicylate. The same compound was also found in the methanol extract of S. longepedunculata from Ghana [71] and in essential oil extracted in Nigeria and Benin [68,69].

\section{C. ambrosioides}

C. ambrosioides essential oil was extracted with a yield of $1.3 \%(\mathrm{w} / \mathrm{w})$. Its essential oil contained mainly ascaridole (41.9\%). Some other components involving $\alpha$-terpinene (16.5\%), $p$-cymene (14.4\%) and isoascaridole (7.5\%) were identified as well. This chemical composition is similar to the one of a sample from China [39] but very different from a sample analyzed in India whose major components were m-cymene (43.9\%) and myrtenol (13.3\%) [72].

\section{Adult bioassay on susceptible strains of Anopheles gambiae}

The resistant status of mosquito samples was determined according to the WHO criteria summarized as follows [42]:

- 98-100\% mortality indicates susceptibility of the mosquito strain to the tested essential oil

- Mortality less than $98 \%$ is suggestive of the existence of a resistance to the essential oil that needs to be confirmed by two additional tests

- Mortality less than 90\% suggests resistance in the mosquito population

\section{$K D T_{50}$ and $K D T_{95}$}

$\mathrm{KDT}_{50}$ and $\mathrm{KDT}_{95}$ calculated with $95 \%$ confidence limits are summarized in Table 7 . The lowest $\mathrm{KDT}_{50}$ and $\mathrm{KDT}_{95}$ values were obtained with $C$. citratus and are 
Table 4 Chemical composition and oil yields of Cochlospermum species

\begin{tabular}{|c|c|c|c|c|c|}
\hline$\overline{\mathrm{Kl}_{\exp }{ }^{\mathrm{a}}}$ & $\mathrm{KI}_{\text {lit }}^{\mathrm{b}}$ & $I^{c}$ & Compounds $^{d}$ & $\begin{array}{l}\text { C. planchonii } \\
\%\end{array}$ & $\begin{array}{l}\text { C. tinctorium } \\
\%\end{array}$ \\
\hline 1025 & 1020 & MS, Rl & p-Cymene & 0.3 & \\
\hline 1100 & 1099 & $M S, R l$ & Undecane & 0.1 & \\
\hline 1154 & 1148 & MS, Rl & Citronellal & 0.2 & \\
\hline 1183 & 1178 & MS, Rl & Naphthalene & 0.1 & \\
\hline 1258 & 1249 & MS, Rl & Piperitone & 0.1 & \\
\hline 1309 & 1305 & MS, Rl & Undecanal & 0.2 & \\
\hline 1382 & 1389 & MS, Rl & $\beta$-Elemene & 1.0 & 0.6 \\
\hline 1388 & 1398 & MS, Rl & Cyperene & 0.1 & 0.1 \\
\hline 1400 & 1408 & MS, Rl & Dodecanal & 0.1 & 0.1 \\
\hline 1405 & 1411 & $M S, R l$ & Z-a-Bergamotene & & 0.1 \\
\hline 1408 & 1417 & MS, Rl & E-Caryophyllene & & 0.1 \\
\hline 1425 & 1432 & MS, Rl & E-a-Bergamotene & & 0.6 \\
\hline 1437 & 1445 & $M S, R l$ & Epi- $\beta$-Santalene & & 0.1 \\
\hline 1492 & 1469 & MS, Rl & 1-Dodecanol & 0.5 & \\
\hline 1493 & 1506 & MS, Rl & Z-a-Bisabolene & & 0.3 \\
\hline 1499 & 1505 & MS, Rl & $\beta$-Bisabolene & & 2.2 \\
\hline 1500 & 1499 & MS, Rl & 2-Tridecanone & 6.8 & 3.4 \\
\hline 1505 & 1514 & MS, Rl & $Z$ Z-Y-Bisabolene & & 0.1 \\
\hline 1512 & 1509 & MS, Rl & Tridecanal & 0.3 & \\
\hline 1513 & 1511 & $M S, R l$ & ઈ-Amorphene & & 0.1 \\
\hline 1515 & 1524 & MS, Rl & Methyl dodecanoate & & 0.5 \\
\hline 1522 & 1529 & MS, Rl & E-y-Bisabolene & & 0.3 \\
\hline 1578 & 1576 & MS, Rl & Dodecanoic acid & 1.2 & \\
\hline 1576 & 1574 & $M S, R l$ & Cyclododecanone & & 7.8 \\
\hline 1585 & 1582 & MS, Rl & Caryophyllene oxide & 0.3 & 0.1 \\
\hline 1598 & & MS & 3-Tetradecanone & 24.7 & 48.3 \\
\hline 1599 & 1607 & MS, Rl & Dodecyl acetate & 4.9 & 2.0 \\
\hline 1602 & 1611 & $M S, R l$ & Tetradecanal & & 0.3 \\
\hline 1663 & 1658 & MS, Rl & Neo-Intermedeol & 0.1 & \\
\hline 1680 & 1685 & MS, Rl & a-Bisabolol & & 0.1 \\
\hline 1695 & 1671 & MS, Rl & n-Tetradecanol & 3.0 & \\
\hline 1702 & 1697 & $M S, R l$ & 2-Pentadecanone & 5.7 & 0.7 \\
\hline 1717 & 1722 & $M S, R l$ & Methyl tetradecanoate & & 2.3 \\
\hline 1775 & 1780 & MS, Rl & Tetradecanoic acid & 0.5 & \\
\hline 1786 & & MS & 3-Hexadecanone & 2.0 & 7.4 \\
\hline 1795 & 1795 & MS, Rl & Ethyl tetradecanoate & 11.4 & \\
\hline 1798 & & MS & 1-Tetradecanyl acetate & & 4.3 \\
\hline 1818 & 1822 & MS, Rl & Hexadecanal & & 0.6 \\
\hline 1846 & 1844 & $M S, R l$ & Isoamyl dodecanoate & 14.1 & \\
\hline 1874 & & MS & Pentadecanol & 2.0 & \\
\hline
\end{tabular}


Table 4 Chemical composition and oil yields of Cochlospermum species (Continued)

\begin{tabular}{|c|c|c|c|c|}
\hline \multirow[t]{3}{*}{2003} & MS & 4-Octadecanone & 2.2 & \\
\hline & & Yields & 0.2 & 0.2 \\
\hline & & Total identified & 81.9 & 82.5 \\
\hline
\end{tabular}

${ }^{\mathrm{a}} \mathrm{Kl}_{\text {exp }}=$ retention indices are determined using n-alkanes $\left(\mathrm{C}_{7}-\mathrm{C}_{17}\right)$.

${ }^{b} \mathrm{Kl}_{\text {lit }}=$ retention indices of reference compounds from literature.

$\mathrm{CID}=$ Identification methods; $\mathrm{MS}=$ comparison of the mass spectrum with those of the computer mass libraries, and Adams (2007); Rl=comparison of calculated RI with those reported in the literature.

${ }^{d}$ Compounds are listed in order of their retention time; the names and the percentages of main compounds are indicated in bold.

respectively $2.1 \mathrm{~min}$ and $13.9 \mathrm{~min}$ at $0.5 \%$ and $1.2 \mathrm{~min}$, $6.6 \mathrm{~min}$ at $1 \%$ whereas for permethrin $(0.75 \%)$ these values were $11.3 \mathrm{~min}$ and $21.6 \mathrm{~min}$. The highest $\mathrm{KDT}_{50}$ and $\mathrm{KDT}_{95}$ values were recorded with $C$. planchonii at $8 \%$ and were $11.3 \mathrm{~min}$ and $20.6 \mathrm{~min}$, respectively.

\section{Mortality rates}

Mortality rates to different essential oils are shown in Table 7. At $0.25 \%$, the mortality rate of A. gambiae "Kisumu" varies from $0.0 \%$ to $72.5 \%$. However, the mortality rates increased with the dosage. At $0.50 \%$, mortality has reached $100 \%$ for C. citratus, whereas it was at $5.6 \%$ for S. longepedunculata. At $1 \%$, mortality was still $100 \%$ for C. citratus whereas it was $6.7 \%$ for C. schoenanthus. At $2 \%$, the mortality rate was $29.6 \%$ for S. longepedunculata and $100 \%$ for C. citratus, E. citriodora, E. tereticornis and C. ambrosioides. At $4 \%$ and $8 \%$, the mortality rates varied from $79.2 \%$ to $100 \%$ for C. tinctorium and C. planchonii. To summarize these results, the susceptibility tests on the sensitive strain A. gambiae "kisumu" have demonstrated its susceptibility status on essential oils tested. The most efficient essential oil was C. citratus at $0.50 \%$, followed by E. tereticornis at $1 \%, E$. citriodora and C. ambrosioides at 2\%, C. schoenanthus, C. giganteus, C. planchonii and S. longepedunculata at $4 \%$.

\section{Diagnostic concentrations}

The diagnostic concentration is defined as twice the lethal concentration (LC) for $99 \%$ mortality ( $\mathrm{LC}_{99}$ ) on sensitive strains [42]. Lethal concentration for $50 \%$ mortality

Table 5 Chemical composition and oil yield of Securidaca longepedunculata

\begin{tabular}{lllll}
\hline $\mathbf{K I}_{\text {exp }}^{\mathbf{a}}$ & $\mathbf{K I}_{\mathbf{l i t}}^{\mathbf{b}}$ & $\mathbf{I D}^{\mathbf{c}}$ & Compounds $^{\mathbf{d}}$ & \% \\
\hline 1194 & 1190 & MS, RI & Methyl salicylate & $\mathbf{9 9 . 4}$ \\
1439 & & MS & Methyl 4-methoxysalicylate & 0.5 \\
& & & Yield & 0.7 \\
& & & Total identified & 99.9
\end{tabular}

${ }^{\mathrm{a}} \mathrm{Kl}_{\text {exp }}=$ retention indices are determined using n-alkanes $\left(C_{7}-C_{17}\right)$.

${ }^{\mathrm{b}} \mathrm{Kl}_{\text {lit }}=$ retention indices of reference compounds from literature.

${ }^{c_{I D}}=$ Identification methods; $M S=$ comparison of the mass spectrum with those of the computer mass libraries, and Adams (2007); RI = comparison of calculated RI with those reported in the literature.

${ }^{\mathrm{d} C o m p o u n d s}$ are listed in order of their retention time: the names and the percentages of main compounds are indicated in bold.
$\left(\mathrm{LC}_{50}\right)$, lethal concentration for $99 \%$ mortality $\left(\mathrm{LC}_{99}\right)$ expressed with 95\% confidence limits and diagnostic concentrations for all essential oils tested are summarized in Table 8.

The lowest diagnostic concentration of $0.77 \%$ for C. citratus was not significantly different from the diagnostic dose of permethrin $(0.75 \%)$. Other interesting values were also obtained for E. tereticornis (2.80\%), E. citriodora (3.37\%), and $C$. ambrosioides (4.26\%). These plant species were followed by $C$. schoenanthus and C. giganteus whose diagnostic concentrations were $5.48 \%$ and $7.36 \%$, respectively. The highest diagnostic doses were obtained with S. longepedunculata (9.84\%), C. tinctorium (11.56\%) and C. planchonii (15.22\%).

All diagnostic doses obtained above were tested on the resistant strain of A. gambiae and results obtained were

Table 6 Chemical composition and oil yield of Chenopodium ambrosioides

\begin{tabular}{|c|c|c|c|c|}
\hline $\mathrm{KI}_{\text {exp }}{ }^{\mathrm{a}}$ & $\mathrm{KI}_{\text {lit }}^{\mathrm{b}}$ & $I^{c}$ & Compounds $^{d}$ & $\%$ \\
\hline 1010 & 1014 & $M S, R I$ & a-Terpinene & 16.5 \\
\hline 1018 & 1020 & $M S, R I$ & p-Cymene & 14.4 \\
\hline 1021 & 1024 & $M S, R I$ & Limonene & 0.4 \\
\hline 1050 & 1054 & MS, RI & y-Terpinene & 0.3 \\
\hline 1114 & 1119 & MS, RI & E-p-Mentha-2,8-dien-1-ol & 0.2 \\
\hline 1145 & 1148 & MS, RI & Citronellal & 0.1 \\
\hline 1175 & 1178 & $M S, R I$ & Naphthalene & 0.1 \\
\hline 1235 & 1234 & MS, RI & Ascaridole & 41.9 \\
\hline 1247 & 1252 & MS, RI & E-Piperitone epoxide & 1.1 \\
\hline 1288 & 1289 & MS, RI & Thymol & 0.4 \\
\hline 1299 & 1299 & $M S, R I$ & Isoascaridole & 7.5 \\
\hline 1347 & 1349 & $M S, R I$ & Thymol acetate & 0.2 \\
\hline 1477 & 1477 & MS, RI & E- $\beta$-Ionone & 0.1 \\
\hline \multirow[t]{3}{*}{1581} & & MS & 3-Tetradecanone & 0.4 \\
\hline & & & Yield & 1.3 \\
\hline & & & Total identified & 83.6 \\
\hline
\end{tabular}

${ }^{\mathrm{a}} \mathrm{Kl}_{\text {exp }}=$ retention indices are determined using $\mathrm{n}$-alkanes $\left(\mathrm{C}_{7}-\mathrm{C}_{17}\right)$.

${ }^{\mathrm{b}} \mathrm{Kl}_{\text {lit }}=$ retention indices of reference compounds from literature.

$\mathrm{C}_{\mathrm{ID}}=$ Identification methods; $\mathrm{MS}=$ comparison of the mass spectrum with those of the computer mass libraries, and Adams (2007); RI = comparison of calculated RI with those reported in the literature.

${ }^{\mathrm{d} C o m p o u n d s}$ are listed in order of their retention time; the names and the percentages of main compounds are indicated in bold. 
Table 7 Knock down times (KDT), mortality and susceptibility of essential oils on sensitive Anopheles gambiae "Kisumu"

\begin{tabular}{|c|c|c|c|c|c|c|c|c|c|c|c|c|}
\hline \multirow{2}{*}{$\begin{array}{l}\text { Doses } \\
\text { Essential oils } \\
\text { and controls }\end{array}$} & \multicolumn{4}{|l|}{$0.25 \%$} & \multicolumn{4}{|l|}{$0.50 \%$} & \multicolumn{4}{|l|}{$1 \%$} \\
\hline & $\mathrm{KDT}_{50}^{\mathrm{a}}(\mathrm{min})$ & $\mathrm{KDT}_{95}{ }^{\mathrm{a}}(\min )$ & Mortality (\%) & Susceptibility ${ }^{\mathbf{b}}$ & $\mathrm{KDT}_{50}{ }^{\mathrm{a}}(\mathrm{min})$ & $\mathrm{KDT}_{95}{ }^{\mathrm{a}}(\min )$ & Mortality (\%) & Susceptibility ${ }^{b}$ & $\mathrm{KDT}_{50}{ }^{\mathrm{a}}(\min )$ & $\mathrm{KDT}_{95}{ }^{\mathrm{a}}(\min )$ & Mortality (\%) & Susceptibility $^{b}$ \\
\hline $\begin{array}{l}\text { Cymbopogon } \\
\text { citratus }\end{array}$ & 62.0 & 119.8 & 55.6 & $R$ & 2.1 & 13.9 & 100 & S & 1.2 & 6.6 & 100 & S \\
\hline $\begin{array}{l}\text { Cymbopogon } \\
\text { giganteus }\end{array}$ & - & - & 10.7 & $\mathrm{R}$ & 204.4 & 366.5 & 10.0 & R & 33.5 & 100.2 & 29.6 & $\mathrm{R}$ \\
\hline $\begin{array}{l}\text { Cymbopogon } \\
\text { schoenanthus }\end{array}$ & - & - & 0.0 & $\mathrm{R}$ & 263.5 & 440.7 & 6.4 & R & 49.0 & 117.8 & 6.7 & $\mathrm{R}$ \\
\hline $\begin{array}{l}\text { Eucalyptus } \\
\text { citriodora }\end{array}$ & - & - & 4.3 & $\mathrm{R}$ & 125.2 & 207.3 & 10.4 & $R$ & 32.2 & 61.7 & 75.5 & $R$ \\
\hline $\begin{array}{l}\text { Eucalyptus } \\
\text { tereticornis }\end{array}$ & 12.4 & 49.8 & 72.5 & $\mathrm{R}$ & 5.4 & 18.2 & 86.7 & R & 2.5 & 16.1 & 98 & S \\
\hline $\begin{array}{l}\text { Cochlospermum } \\
\text { tinctorium }\end{array}$ & 44.3 & 115.6 & 23.3 & $\mathrm{R}$ & 10.6 & 19.4 & 44.0 & $\mathrm{R}$ & 8.1 & 16.7 & 72.7 & $\mathrm{R}$ \\
\hline $\begin{array}{l}\text { Cochlospermum } \\
\text { planchonii }\end{array}$ & 34.5 & 74.1 & 13.0 & $\mathrm{R}$ & 25.1 & 52.8 & 23.6 & R & 20.9 & 39.9 & 24.5 & $\mathrm{R}$ \\
\hline $\begin{array}{l}\text { Securidaca } \\
\text { longepedunculata }\end{array}$ & - & - & 5.9 & $\mathrm{R}$ & 314.1 & 539.5 & 5.6 & R & 76.2 & 91.3 & 8.6 & R \\
\hline $\begin{array}{l}\text { Chenopodium } \\
\text { ambrosioides }\end{array}$ & 736.3 & 1290.0 & 9.8 & $\mathrm{R}$ & 127.8 & 201.3 & 18.8 & R & 110.9 & 178.9 & 41.9 & R \\
\hline Permethrin $0.75 \%$ & 11.3 & 21.6 & 100 & s & 11.3 & 21.6 & 100 & S & 11.3 & 21.6 & 100 & S \\
\hline Negative control & 0 & 0 & 0 & - & 0 & 0 & 0 & - & 0 & 0 & 0 & - \\
\hline Doses & \multicolumn{4}{|l|}{$2 \%$} & \multicolumn{4}{|l|}{$4 \%$} & \multicolumn{4}{|l|}{$8 \%$} \\
\hline $\begin{array}{l}\text { Essential oils and } \\
\text { controls }\end{array}$ & $\mathrm{KDT}_{50}{ }^{\mathrm{a}}(\mathrm{min})$ & $\mathrm{KDT}_{95}{ }^{\mathrm{a}}(\mathrm{min})$ & Mortality (\%) & Susceptibility $^{b}$ & $\mathrm{KDT}_{50}{ }^{\mathrm{a}}(\min )$ & $\mathrm{KDT}_{95}{ }^{\mathrm{a}}(\mathrm{min})$ & Mortality (\%) & Susceptibility $^{\mathrm{b}}$ & $\mathrm{KDT}_{50}{ }^{\mathrm{a}}(\mathrm{min})$ & $\mathrm{KDT}_{95}{ }^{\mathrm{a}}(\min )$ & Mortality (\%) & Susceptibility $^{\mathbf{b}}$ \\
\hline $\begin{array}{l}\text { Cymbopogon } \\
\text { citratus }\end{array}$ & - & 3.8 & 100 & S & - & 3.8 & 100 & S & - & - & - & - \\
\hline $\begin{array}{l}\text { Cymbopogon } \\
\text { giganteus }\end{array}$ & 6.2 & 9.5 & 62.7 & $\mathrm{R}$ & 2.6 & 3.8 & 100 & S & - & - & - & - \\
\hline $\begin{array}{l}\text { Cymbopogon } \\
\text { schoenanthus }\end{array}$ & 6.9 & 14.5 & 83.0 & $\mathrm{R}$ & 2.6 & 3.8 & 100 & S & - & - & - & - \\
\hline $\begin{array}{l}\text { Eucalyptus } \\
\text { citriodora }\end{array}$ & 4.5 & 9.0 & 100 & s & 2.6 & 3.8 & 100 & S & - & - & - & - \\
\hline $\begin{array}{l}\text { Eucalyptus } \\
\text { tereticornis }\end{array}$ & - & 3.8 & 100 & S & - & 3.3 & 100 & S & - & - & - & - \\
\hline $\begin{array}{l}\text { Cochlospermum } \\
\text { tinctorium }\end{array}$ & 6.9 & 12.3 & 78.1 & $\mathrm{R}$ & 5.2 & 9.1 & 79.2 & R & - & - & - & - \\
\hline $\begin{array}{l}\text { Cochlospermum } \\
\text { planchonii }\end{array}$ & 16.3 & 31.3 & 58.5 & $\mathrm{R}$ & 12.1 & 21.1 & 98.3 & S & 11.3 & 20.6 & 100 & S \\
\hline $\begin{array}{l}\text { Securidaca } \\
\text { longepedunculata }\end{array}$ & 10.9 & 81.0 & 29.6 & $\mathrm{R}$ & 2.6 & 3.8 & 98.2 & S & 2.6 & 3.8 & 100 & S \\
\hline
\end{tabular}


Table 7 Knock down times (KDT), mortality and susceptibility of essential oils on sensitive Anopheles gambiae "Kisumu" (Continued)

\begin{tabular}{llllllllll}
\hline $\begin{array}{l}\text { Chenopodium } \\
\text { ambrosioides }\end{array}$ & 12.8 & 25.2 & 100 & $\mathrm{~S}$ & 2.6 & 3.8 & 100 & $\mathrm{~S}$ & - \\
Permethrin $\mathbf{0 . 7 5 \%}$ & 11.3 & 21.6 & 100 & $\mathrm{~S}$ & 11.3 & 21.6 & 100 & $\mathrm{~S}$ & - \\
Negative control & 0 & 0 & 0 & - & 0 & 0 & 0 & - & 0 \\
\hline
\end{tabular}

The KDT (KDT ${ }_{50}$ and $\left.\mathrm{KDT}_{95}\right)$ values were expressed with $95 \%$ confidence limits.

${ }^{\mathrm{b}} \mathrm{S}=$ Susceptible defined as $98-100 \%$ of mortality; RS = Resistance suspected defined as $90-97 \%$ of mortality; R= Resistance defined as $<90 \%$ of mortality 
Table 8 LC $_{50}, L_{99}$ and diagnostic concentration for all essential oils tested

\begin{tabular}{|c|c|c|c|c|c|}
\hline \multirow[t]{2}{*}{ Essential oils } & \multirow{2}{*}{$\begin{array}{l}\mathrm{LC}_{50}{ }^{\mathrm{a}} \\
\%\end{array}$} & \multirow{2}{*}{$\begin{array}{l}\mathrm{LC}_{99}{ }^{\mathrm{a}} \\
\%\end{array}$} & \multirow{2}{*}{$\begin{array}{l}\text { Diagnostic } \\
\text { concentration } \\
\%\end{array}$} & \multirow{2}{*}{$\begin{array}{l}\text { Diagnostic } \\
\text { concentration } \\
\mathrm{mg} / \mathrm{ml}\end{array}$} & \multirow{2}{*}{$\begin{array}{l}\text { Diagnostic } \\
\text { concentration } \\
\mathrm{mg} / \mathrm{cm}^{2}\end{array}$} \\
\hline & & & & & \\
\hline Cymbopogon citratus & 0.237 & 0.386 & 0.77 & 7.7 & 0.085 \\
\hline Cymbopogon giganteus & 1.600 & 3.682 & 7.36 & 73.6 & 0.82 \\
\hline Cymbopogon schoenanthus & 1.570 & 2.739 & 5.48 & 54.8 & 0.60 \\
\hline Eucalyptus citriodora & 0.900 & 1.685 & 3.37 & 33.7 & 0.37 \\
\hline Eucalyptus tereticornis & 0.148 & 1.401 & 2.80 & 28.0 & 0.31 \\
\hline Cochlospermum tinctorium & 1.16 & 5.781 & 11.56 & 115.6 & 1.28 \\
\hline Cochlospermum planchonii & 2.314 & 7.608 & 15.22 & 152.2 & 1.69 \\
\hline Securidaca longepedunculata & 2.489 & 4.919 & 9.84 & 98.4 & 1.09 \\
\hline Chenopodium ambrosioides & 0.997 & 2.131 & 4.26 & 42.6 & 0.47 \\
\hline
\end{tabular}

$\mathrm{LC}_{50}$ : lethal concentration for $50 \%$ mortality; $\mathrm{LC}_{99}$ : lethal concentration for $99 \%$ mortality.

${ }^{\mathrm{a}}$ The lethal doses $\left(\mathrm{LC}_{50}\right.$ and $\mathrm{LC} \mathrm{C}_{95}$ ) values were expressed with $95 \%$ confidence limits.

summarized in Table 9. Concerning the diagnostic doses tested, the lowest $\mathrm{KDT}_{50}$ and $\mathrm{KDT}_{95}$ were observed with C. schoenanthus (2.58 $\mathrm{min}, 3.84 \mathrm{~min}$ ), followed by S. longepedunculata, C. giganteus, E. tereticornis, C. ambrosioides and E. citriodora for which the $\mathrm{KDT}_{50}$ and $\mathrm{KDT}_{95}$ were lower than $5 \mathrm{~min}$ and $6 \mathrm{~min}$, respectively. A moderate knock down effect $\left(\mathrm{KDT}_{50} \geq 12 \mathrm{~min}\right.$ and $\mathrm{KDT}_{95} \geq 20 \mathrm{~min}$ ) was observed with C. planchonii, C. tinctorium and C. citratus.

The $\mathrm{KDT}_{50}$ observed was 6 to 35 fold lower than for permethrin, the positive control, and the $\mathrm{KDT}_{95}$ was 5 to 38 fold lower than permethrin. This observation demonstrates the promising insecticidal properties of these plants species on the $A$. gambiae resistant strain used.

Apart from the essential oil from C. tinctorium and $S$. longepedunculata for which resistance was suspected because the mortality was less than $97 \%$, the resistant strain of A. gambiae was susceptible to all essential oils at diagnostic doses tested (Table 9). The resistance to permethrin in southern Benin has been demonstrated and was explained by the massive use of DDT in house spraying and agriculture, during the WHO malaria eradication program, which has permitted the apparition and the increase of $k d r$ mutation in A. gambiae populations in Benin $[7,10]$.

We have noticed that the knock-down times, the mortalities, and the resistance status of $A$. gambiae did not only depend on the values of doses used but mainly on the chemical composition of essential oils used.

Larvicidal activity of $C$. citratus essential oil on Aedes aegypti at lower concentrations $\left(\mathrm{LC}_{50}=0.28 \mu \mathrm{l} / \mathrm{ml}\right.$ and $\mathrm{LC}_{90}=0.56 \mu \mathrm{l} / \mathrm{ml}$ ) and its major component citral (neral and geranial) has been demonstrated by Freitas et al. [73]. C. citratus has also demonstrated a very good repellency against $A$. aegypti [30]. C. citratus has shown in the current study the best insecticidal activity against A. gambiae, but its $\mathrm{KDT}_{50}$ and $\mathrm{KDT}_{90}$ were higher than

Table $9 \mathrm{KDT}_{50}, \mathrm{KDT}_{95}$ and mortality of essential oils tested on the resistant strain of Anopheles gambiae

\begin{tabular}{|c|c|c|c|c|c|}
\hline Essential oils & $\begin{array}{l}\text { Diagnostic doses } \\
\text { (\%) }\end{array}$ & $\begin{array}{l}\mathrm{KDT}_{50}{ }^{\mathrm{a}} \\
(\mathrm{min})\end{array}$ & $\begin{array}{l}\mathrm{KDT}_{95}{ }^{\mathrm{a}} \\
(\mathrm{min})\end{array}$ & $\begin{array}{l}\text { Mortality } \\
\%\end{array}$ & Susceptibility $^{\mathbf{b}}$ \\
\hline Cymbopogon citratus & 0.77 & 15.77 & 26.00 & 100 & $\mathrm{~S}$ \\
\hline Cymbopogon giganteus & 7.36 & 2.92 & 5.53 & 100 & $\mathrm{~S}$ \\
\hline Cymbopogon schoenanthus & 5.48 & 2.58 & 3.84 & 100 & $\mathrm{~S}$ \\
\hline Eucalyptus citriodora & 3.37 & 4.02 & 5.93 & 100 & $\mathrm{~S}$ \\
\hline Eucalyptus tereticornis & 2.80 & 3.56 & 5.27 & 100 & $\mathrm{~S}$ \\
\hline Cochlospermum tinctorium & 11.56 & 12.01 & 20.67 & 90.4 & RS \\
\hline Cochlospermum planchonii & 15.22 & 11.35 & 30.72 & 100 & $\mathrm{~S}$ \\
\hline Securidaca longepedunculata & 9.84 & 2.87 & 4.47 & 94.8 & RS \\
\hline Chenopodium ambrosioides & 4.26 & 3.96 & 5.84 & 98.0 & $\mathrm{~s}$ \\
\hline Permethrin $0.75 \%$ & 0.75 & 90.87 & 145.37 & 62.3 & $\mathrm{R}$ \\
\hline
\end{tabular}

$\mathrm{KDT}_{50}$ : 50\% knock down in mosquito's population; $\mathrm{KDT}_{95}: 95 \%$ knock down in mosquito's population.

${ }^{a}$ The KDT (KDT 50 and $\mathrm{KDT}_{95}$ ) values were expressed with $95 \%$ confidence limits.

${ }^{\mathrm{b}} \mathrm{S}=$ Susceptible defined as $98-100 \%$ of mortality; RS = Resistance suspected defined as $90-97 \%$ of mortality; R= Resistance defined as < $90 \%$ of mortality. 
some of the other essential oils. The same conclusion has been found by Phasomkusolsil et al. [33] when the essential oil was tested on $A$. aegypti, C. quinquefasciatus and Anopheles dirus. The topical application of C. citratus showed high toxicity against Sitophilus oryzae [50]. C. citratus essential oil and citral have been shown to be potential anti-Leishmania agents [51]. Insecticidal and larvicidal activities of $C$. citratus have been attributed to citral that has demonstrated $100 \%$ mortality against $A$. aegypti, at $2.5 \mu \mathrm{l} / \mathrm{ml}$ with $\mathrm{LC}_{50}=0.02 \mu \mathrm{l} / \mathrm{ml}$ and $\mathrm{LC}_{90}=$ $0.28 \mu \mathrm{l} / \mathrm{ml}$ respectively [73], and its repellent effect at $15 \%(\mathrm{v} / \mathrm{v})$ is comparable to $5 \%$ C. citratus essential oil [74]. In conclusion, the presence of geranial and neral is potentially responsible for the insecticidal activity of the essential oil of $C$. citratus, as demonstrated in the current work.

C. giganteus essential oil, rich in limonene and $(Z$ and $E)$-p-mentha-1(7),8-dien-2-ol such as the current sample from Benin, has proven to be toxic by fumigation to Callosobruchus species [28]. The insecticidal properties noticed in this study against $A$. gambiae might also be attributed to these main compounds.

Several studies on essential oils, rich in piperitone such as the essential oil from $C$. schoenanthus have demonstrated insecticidal activity against some pests. This is the case for Cymbopogon olivieri, which demonstrated good larvicidal activity against $A$. stephensi with $\mathrm{LD}_{50}=$ $321.9 \mathrm{mg} / \mathrm{l}$ [75]. Exposure of Callosobruchus maculatus to C. schoenanthus essential oil for 24 hours resulted in $90 \%$ of adult mortality at $6.7 \mu \mathrm{l} / \mathrm{l}$ [56]. Piperitone has been reported to be powerful against ants of Crematogaster spp [76]. Adults, newly laid eggs and neonate larvae of C. maculatus with an $\mathrm{LC}_{50}$ recorded at $1.6 \pm 0.14 \mu \mathrm{l} / \mathrm{l}$ and all eggs were aborted at $6.7 \mu \mathrm{l} / \mathrm{l}$ with a total inhibition of the neonate larvae penetration in the seed [38]. Also in 2008, piperitone isolated from Artemisia judaica L., was studied against the third larvae of Spodoptera littoralis (Boisd) and has revealed a high insecticidal and antifeedant activity against this pathogen, with a $\mathrm{LD}_{50}=0.68 \mu \mathrm{g} /$ larvae [77]. Following this previous research we could attribute the insecticidal activity of C. schoenanthus to its main compound, i.e. piperitone.

The essential oil from E. citriodora, rich in citronellal, citronellol and isopulegol, has been revealed to be repellent against Tribolium castaneum at $0.084 \mathrm{ml} / \mathrm{l}$ and was more active than the commercial product IR3535 at $0.686 \mathrm{ml} / \mathrm{l}$ [41]. The insecticidal activity of E. citriodora has been demonstrated at $5 \mathrm{mg} / \mathrm{ml}$ against Lutzomyia longipalpis [27]. E. citriodora has also demonstrated larvicidal activity against C. quinquefasciatus [36] and acaricidal activity against larvae of Amblyomma cajennense and Anocentor nitens [78]. The presence of citronellal, citronellol and isopulegol could well explain the insecticidal activity of E. citriodora against A. gambiae.
The essential oil from E. tereticornis leaf extract has shown a larvicidal activity against $A$. stephensi at $160 \mathrm{ppm}$ which has provoked $100 \%$ of oviposition deterrence [35]. The sensitivity of adults of $A$. aegypti has been shown, resulting from the presence of 1,8 -cineole, $\alpha$-pinene and $p$-cymene and is correlated to the amount of 1,8-cineole in the extract $[26,60]$. The insecticidal activity of the essential oil of E. tereticornis observed in the current work, might be explained by the presence of one of its major components ( $p$-cymene) but also by a minor compound (1,8-cineole), which both have demonstrated insecticidal activity.

In essential oils from Cochlospermum species one minor compound (2-tridecanone) has been found to have insect repellent properties. Indeed, 2-tridecanone has demonstrated repellent activity against the granary weevil Sitophilus granarius and S. zeamais at $100 \mathrm{ppm}$ and $500 \mathrm{ppm}$ on wheat [79]. Its repellent activity was confirmed against ticks since $0.63 \mathrm{mg} / \mathrm{cm}^{2}$ was repellent to $87 \%$ of Amblyomma americanum after 12 hours and to $72 \%$ of Dermacentor variabilis after 15 hours [80]. The weak insecticidal activity of the essential oils of these two Cochlospermum species could be due to the low abundancy of 2-tridecanone.

Root powder, the methanol extract, and the main volatile component of $S$. longepedunculata (methyl salicylate) have proven to exhibit repellent and toxic effects against $S$. zeamais. In the same study, methyl salicylate has demonstrated a dose dependent fumigant effect with an $\mathrm{LD}_{100}$ of $60 \mu \mathrm{l}$ in a 1-l container after 24 hours exposure on S. zeamais, Rhyzopertha dominica and Prostephanus truncates and after 6 days exposure, 100\% mortality could be recorded with $30 \mu \mathrm{l}$ in a 1-1 container [31].

The $C$. ambrosioides essential oil has demonstrated a larvicidal activity against $A$. arabiensis and $A$. aegypti after 24 hours exposure with $\mathrm{LC}_{50}$ and $\mathrm{LC}_{90}$ equal to $17.5 \mathrm{ppm}$ and $33.2 \mathrm{ppm}$ for A. arabiensis and $9.1 \mathrm{ppm}$ and $14.3 \mathrm{ppm}$ for $A$. aegypti under laboratory conditions [81]. Contact and fumigant toxicity of isolated compounds from this plant species have shown that ascaridole $\left(\mathrm{LC}_{50}=\right.$ $0.84 \mathrm{mg} / \mathrm{l})$ followed by isoascaridole $\left(\mathrm{LC}_{50}=2.45 \mathrm{mg} / \mathrm{l}\right)$ were the most efficient insecticidal compounds by fumigation and contact with $\mathrm{LC}_{50}=0.86 \mathrm{mg} / \mathrm{l}$ (ascaridole) and $2.16 \mathrm{mg} / \mathrm{l}$ (isoascaridole). The crude oil was less active with $\mathrm{LC}_{50}=3.08 \mathrm{mg} / \mathrm{l}$ by fumigation and $2.12 \mathrm{mg} / \mathrm{l}$ by contact [39]. The insecticidal activity of $C$. ambrosioides, noticed in the study, might be explained by the presence of ascaridole and isoascaridole, which were among its major constituents.

\section{Conclusions}

The current study has dealt with the insecticidal properties of essential oils of nine plant species traditionally used in Benin for their repellency against $A$. gambiae bites. This 
research has shown that the essential oils from all the plant species studied, have insecticidal properties against this vector of malaria. The most promising was C. citratus followed in order of effectiveness by E. tereticornis, E. citriodora, C. ambrosioides, C. schoenanthus, C. giganteus and C. planchonii. The chemical composition of each plant essential oil has been elucidated by GC-MS and correlated with the insecticidal properties of these plant species. To our knowledge, it was the first time that diagnostic doses of essential oils on $A$. gambiae were determined, using the WHO susceptibility test protocol. These doses were presented in $\%, \mathrm{mg} / \mathrm{ml}$ and $\mathrm{mg} / \mathrm{cm}^{2}$ to facilitate further research on these plant species. $\mathrm{KDT}_{50}$ and $\mathrm{KDT}_{95}, \mathrm{LC}_{50}$ and $\mathrm{LC}_{99}$ and results obtained have proven that all essential oils from these plant species are more effective against the resistant strain of A. gambiae than permethrin at the diagnostic doses tested. C. citratus, E. tereticornis, E. citriodora and C. ambrosioides as well as essential oil isolated components, such as citral, piperitone, 1,8-cineole, citronellal, 2-tridecanone, methyl salicylate, which possess demonstrated insecticidal properties, may be included in malaria vector control programs. These plants, occurring in the natural environment of local populations, could be obtained at lower cost and represent today a valuable source of bioactive compounds for the protection of the population against malaria.

\section{Competing interests}

The authors declare that they have no competing interests.

\section{Authors' contributions}

$A D B, F A, D C K S, S M, N D K$ and MCA have defined the study. HPY has conducted the identification and the harvesting of the plant species. ADB and PMB have performed the experiments and interpretation of data. SM, NDK, DCKS, FA, PMB, MCA and ADB drafted and revised the manuscript. All authors read and approved the final version of the manuscript.

\section{Aknowledgment}

We are grateful to the team of the Centre de Recherche en Entomologie de Cotonou, for the realization of insecticidal tests on $\mathrm{A}$. gambiae, as well as to the Belgian Technical Cooperation, Ghent University and the Research Foundation-Flanders for financial support of this research.

\section{Author details}

'Laboratoire d'Etude et de Recherche en Chimie Appliquée, Ecole Polytechnique d'Abomey-Calavi, Université d'Abomey-Calavi, Cotonou 01 BP 2009, Bénin. ${ }^{2}$ Department of Sustainable Organic Chemistry and Technology, Faculty of Bioscience Engineering, Ghent University, Coupure links 653, Ghent B-9000, Belgium. ${ }^{3}$ Herbier National du Bénin, Laboratoire de Botanique et Ecologie Végétale, Université d'Abomey-Calavi, Cotonou 01 BP 4521, Bénin. ${ }^{4}$ Centre de Recherche en Entomologie de Cotonou, Cotonou 06 BP 2604, Bénin.

Received: 10 October 2013 Accepted: 21 November 2013 Published: 3 December 2013

\section{References}

1. WHO: World malaria report 2012. Geneva: World Health Organization; 2012.

2. Chandre F, Darriet F, Manguin S, Brengues C, Carnevale P, Guillet P: Pyrethroid cross resistance spectrum among populations of Anopheles gambiae s.s. from Cote d'Ivoire. J Am Mosquito Contr 1999, 15:53-59.
3. Diabate A, Baldet T, Chandre F, Akogbeto M, Guiguemde TR, Darriet F, Brengues C, Guillet P, Hemingway J, Small GJ, Hougar JM: The role of agricultural use of insecticides in resistance to pyrethroids in Anopheles gambiae sl in Burkina Faso. Am J Trop Med Hyg 2002, 67:617-622.

4. Aikpon R, Agossa F, Osse R, Oussou O, Aizoun N, Oke-Agbo F, Akogbeto M: Bendiocarb resistance in Anopheles gambiae s.l. populations from Atacora department in Benin, West Africa: a threat for malaria vector control. Parasit Vectors 2013, 6:192-198.

5. Aizoun N, Osse R, Azondekon R, Alia R, Oussou O, Gnanguenon V, Aikpon R, Padonou G, Akogbeto M: Comparison of the standard WHO susceptibility tests and the CDC bottle bioassay for the determination of insecticide susceptibility in malaria vectors and their correlation with biochemical and molecular biology assays in Benin, West Africa. Parasit Vectors 2013, 6:147-156.

6. Corbel V, N'Guessan R, Brengues C, Chandre F, Djogbenou L, Martin T, Akogbeto M, Hougard JM, Rowland M: Multiple insecticide resistance mechanisms in Anopheles gambiae and Culex quinquefasciatus from Benin, West Africa. Acta Trop 2007, 101:207-216.

7. Djegbe I, Boussari O, Sidick A, Martin T, Ranson H, Chandre F, Akogbeto M, Corbel V: Dynamics of insecticide resistance in malaria vectors in Benin: first evidence of the presence of L1014S kdr mutation in Anopheles gambiae from West Africa. Malaria J 2011, 10:261-271.

8. Padonou GG, Sezonlin M, Osse R, Aizoun N, Oke-Agbo F, Oussou O, Gbedjissi G, Akogbeto M: Impact of three years of large scale Indoor Residual Spraying (IRS) and Insecticide Treated Nets (ITNs) interventions on insecticide resistance in Anopheles gambiae s.l. in Benin. Parasit Vectors 2012, 5:72-82.

9. Yadouleton AW, Asidi A, Djouaka RF, Braima J, Agossou CD, Akogbeto MC: Development of vegetable farming: a cause of the emergence of insecticide resistance in populations of Anopheles gambiae in urban areas of Benin. Malaria J 2009, 8:103-110.

10. Yadouleton AW, Padonou G, Asidi A, Moiroux N, Bio-Banganna S, Corbel V, N'Guessan R, Gbenou D, Yacoubou I, Gazard K, Akogbeto MC: Insecticide resistance status in Anopheles gambiae in southern Benin. Malaria J 2010, 9:83-88.

11. Ahoua Alou LP, Koffi AA, Adja MA, Assi SB, Kouassi PK, N'Guessan R: Status of pyrethroid resistance in Anopheles gambiae s.s. M form prior to the scaling up of Long Lasting Insecticidal Nets (LLINs) in Adzope, Eastern Cote d'Ivoire. Parasit Vectors 2012, 5:289-294.

12. Czeher C, Labbo R, Arzika I, Duchemin J-B: Evidence of increasing Leu-Phe knockdown resistance mutation in Anopheles gambiae from Niger following a nationwide long-lasting insecticide-treated nets implementation. Malaria J 2008, 7:189-200.

13. Dabire RK, Namountougou M, Sawadogo SP, Yaro LB, Toe HK, Ouari A Gouagna LC, Simard F, Chandre F, Baldet T, et al: Population dynamics of Anopheles gambiae s.l. in Bobo-Dioulasso city: bionomics, infection rate and susceptibility to insecticides. Parasit Vectors 2012, 5:127-135.

14. Diabate A, Brengues $C$, Baldet T, Dabire KR, Hougard JM, Akogbeto M, Kengne P, Simard F, Guillet P, Hemingway J, Chandre F: The spread of the Leu-Phe kdr mutation through Anopheles gambiae complex in Burkina Faso: genetic introgression and de novo phenomena. Trop Med Int Health 2004, 9:1267-1273.

15. Fanello C, Petrarca V, Della Torre A, Santolamazza F, Dolo G, Coulibaly M, Alloueche A, Curtis CF, Touré YT, Coluzzi M: The pyrethroid knock-down resistance gene in the Anopheles gambiae complex in Mali and further indication of incipient speciation within An. gambiae s.s. Insect Mol Biol 2003, 12:241-245.

16. Awolola TS, Brooke BD, Hunt RH, Coetze M: Resistance of the malaria vector Anopheles gambiae s.s. to pyrethroid insecticides, in southwestern Nigeria. Ann Trop Med Parasitol 2002, 96:849-852.

17. Vulule JM, Beach RF, Atieli FK, MCAllister JC, Brogdon WG, Roberts JM, Mwangi RW, Hawley WA: Elevated oxidase and esterase levels associated with permethrin tolerance in Anopheles gambiae from Kenyan villages using permethrin-impregnated nets. Med Vet Entomol 1999, 13:239-244.

18. Etang J, Chandre F, Guillet P, Manga L: Reduced bio-efficacy of permethrin EC impregnated bednets against an Anopheles gambiae strain with oxidase-based pyrethroid tolerance. Malaria J 2004, 3:46-52.

19. Etang J, Chouaibou M, Toto JC, Faye O, Manga L, Same-Ekobo A, Awono-Ambene $P$, Simard F: A preliminary test of the protective efficacy of permethrin-treated bed nets in an area of Anopheles gambiae metabolic resistance to pyrethroids in north Cameroon. Trans R Soc Trop Med Hyg 2007, 101:881-884. 
20. Nwane P, Etang J, Chouaibou M, Toto J, Koffi A, Mimpfoundi R, Simard F: Multiple insecticide resistance mechanisms in Anopheles gambiae s.l. populations from Cameroon, Central Africa. Parasit Vectors 2013, 6:41-54

21. Haji K, Khatib B, Smith S, Ali A, Devine G, Coetzee M, Majambere S: Challenges for malaria elimination in Zanzibar: pyrethroid resistance in malaria vectors and poor performance of long-lasting insecticide nets. Parasit Vectors 2013, 6:82-90.

22. Okia M, Ndyomugyenyi R, Kirunda J, Byaruhanga A, Adibaku S, Lwamafa D, Kironde F: Bioefficacy of long-lasting insecticidal nets against pyrethroid-resistant populations of Anopheles gambiae s.s. from different malaria transmission zones in Uganda. Parasit Vectors 2013, 6:130-139.

23. Overgaard HJ, Reddy VP, Abaga S, Matias A, Reddy MR, Kulkarni V, Schwabe C, Segura L, Kleinschmidt I, Slotman MA: Malaria transmission after five years of vector control on Bioko Island, Equatorial Guinea. Parasit Vectors 2012, 5:253-266

24. Hunt RH, Fuseini G, Knowles S, Stiles-Ocran J, Verster R, Kaiser ML, Choi KS, Koekemoer $\mathrm{LL}$, Coetzee $\mathrm{M}$ : Insecticide resistance in malaria vector mosquitoes at four localities in Ghana, West Africa. Parasit Vectors 2011 4:107-113.

25. Batish DR, Singh HP, Kohli RK, Kaur S: Eucalyptus essential oil as a natural pesticide. Forest Ecol Manag 2008, 256:2166-2174.

26. Lucia A, Licastro S, Zerba E, Audino PG, Masuh H: Sensitivity of Aedes aegypti adults (Diptera: Culicidae) to the vapors of Eucalyptus essential oils. Bioresour Technol 2009, 100:6083-6087.

27. Maciel MV, Morais SM, Bevilaqua CML, Silva RA, Barros RS, Sousa RN, Sousa LC, Brito ES, Souza-Neto MA: Chemical composition of Eucalyptus spp. essential oils and their insecticidal effects on Lutzomyria longipalpis. Vet Parasitol 2010, 167:1-7.

28. Nyamador WS, Ketoh GK, Amevoin K, Nuto Y, Koumaglo HK, Glitho IA: Variation in the susceptibility of two Callosobruchus species to essential oils. J Stored Prod Res 2010, 46:48-51.

29. Palacios SM, Bertoni A, Rossi Y, Santander R, Urzua A: Insecticidal activity of essential oils from native medicinal plants of Central Argentina against the house fly, Musca domestica (L.). Parasitol Res 2009, 106:207-212.

30. Phasomkusolsil S, Soonwera M: Efficacy of herbal essential oils as insecticide against Aedes aegypti (Linn.), Culex quinquefasciatus (Say) and Anopheles dirus (Peyton and Harrison). Southeast Asian J Trop Med Public Health 2011, 42:1083-1092.

31. Jayasekara TK, Stevenson PC, Hall DR, Belmain SR: Effect of volatile constituents from Securidaca longepedunculata on insect pests of stored grain. J Chem Ecol 2005, 31:303-313.

32. Kweka EJ, Nyindo M, Mosha F, Silva AG: Insecticidal activity of the essential oil from fruits and seeds of Schinus terebinthifolia Raddi against African malaria vectors. Parasit Vectors 2011, 4:129-138.

33. Phasomkusolsil S, Soonwera M: Comparative mosquito repellency of essential oils against Aedes aegypti (Linn.), Anopheles dirus (Peyton and Harrison) and Culex quinquefasciatus (Say). Asian Pac J Trop Biomed 2011, 1(1):113-118.

34. Sutthanont $\mathrm{N}$, Choochote W, Tuetun B, Junkum A, Jitpakdi A, Chaithong U, Riyong D, Pitasawa B: Chemical composition and larvicidal activity of edible plant-derived essential oils against the pyrethroid susceptible and resistant strains of Aedes aegypti (Diptera: Culicidae). J Vector Ecol 2010, 35:106-115

35. Senthil Nathan S: The use of Eucalyptus tereticornis Sm: (Myrtaceae) oil (leaf extract) as a natural larvicidal agent against the malaria vector Anopheles stephensi Liston (Diptera: Culicidae). Bioresour Technol 2007, 98:1856-1860

36. Idris HS, Lawal SB, Balarabe BM: Larvicidal potentials of leaf and bark extracts of Eucalyptus camaldulensis (Schlect) and Eucalyptus citriodora (Hook) on Culex quinquefasciatus (Say) larvae. Entomol Res 2008, 38:243-249

37. Boeke SJ, Baumgart IR, van Loon JJA, van Huis A, Dicke M, Kossou DK: Toxicity and repellence of African plants traditionally used for the protection of stored cowpea against Callosobruchus maculatus. J Stored Prod Res 2004, 40:423-438.

38. Ketoh GK, Koumaglo HK, Glitho IA, Huignard J: Comparative effects of Cymbopogon schoenanthus essential oil and piperitone on Callosobruchus maculatus development. Fitoterapia 2006, 77:506-510.

39. Chu SS, Feng Hu J, Liu ZL: Composition of essential oil of Chinese Chenopodium ambrosioides and insecticidal activity against maize weevil, Sitophilus zeamais. Pest Manag Sci 2011, 67:714-718.
40. Tapondjou LA, Adler C, Bouda H, Fontem DA: Efficacy of powder and essential oil from Chenopodium ambrosioides leaves as post-harvest grain protectants against six-stored product beetles. J Stored Prod Res 2002, 38:395-402.

41. Olivero-Verbel J, Nerio LS, Stashenko EE: Bioactivity against Tribolium castaneum Herbst (Coleoptera: Tenebrionidae) of Cymbopogon citratus and Eucalyptus citriodora essential oils grown in Colombia. Pest Manag Sci 2010, 66:664-668.

42. WHO: Test procedures for insecticide resistance monitoring in malaria vector mosquitoes. Geneva: World Health Organization; 2013

43. Akoègninou A, van der Burg WJ, van der Maesen LJG: Flore analytique du Bénin. Cotonou\&Wageningen: Backhuys Publishers; 2006.

44. Adams RP: Identification of essential oil components by Gas Chromatography/ Mass Spectrometry. 4th edition. Illinois: Allured Publishing Corporation; 2007.

45. The Pherobase-Database of pheromones and semiochemicals. http://www. pherobase.com/.

46. Chemistry WebBook. http://www.nist.gov/index.html.

47. Flavornet and human odor space. [http://www.flavornet.org/].

48. WHO: Guidelines for testing mosquito adulticides for indoor residual spraying and treatment of mosquito nets. Geneva: World Health Organization; 2006.

49. Andrade EHA, Zoghbi MGB, Lima MD: Chemical composition of the essential oils of Cymbopogon citratus (DC.) stapf cultivated in North of Brazil. J Essent Oil Bear PI 2009, 12:41-45.

50. Franz AR, Knaak N, Fiuza LM: Toxic effects of essential plant oils in adult Sitophilus oryzae (Linnaeus) (Coleoptera, Curculionidae). Rev Bras Entomol 2011, 55:116-120.

51. Machado M, Pires P, Dinis AM, Santos-Rosa M, Alves V, Salqueiro L, Cavaleiro C, Sousa MC: Monoterpenic aldehydes as potential anti-Leishmania agents: Activity of Cymbopogon citratus and citral on L. infantum, L. tropica and L. major. Exp Parasitol 2012, 130:223-231.

52. Menut C, Bessiere JM, Samate D, Djibo AK, Buchbauer G, Schopper B: Aromatic plants of tropical West Africa. XI: chemical composition, antioxidant and antiradical properties of the essential oils of three Cymbopogon species from Burkina Faso. J Essent Oil Res 2000, $12: 207-212$

53. Jirovetz L, Buchbauer G, Eller G, Ngassourn MB: Composition and antimicrobial activity of Cymbopogon giganteus (Hochst.) chiov. essential flower, leaf and stem oils from Cameroon. J Essent Oil Res 2007, 19:485-489.

54. Kanko C, Sawaliho BE-H, Kone S, Koukoua G, N'Guessan YT: Étude des propriétés physico-chimiques des huiles essentielles de Lippia multiflora, Cymbopogon citratus, Cymbopogon nardus, Cymbopogon giganteus. CR Chimie 2004, 7:1039-1042.

55. Sidibé L, Chalchat J-C, Garry R-P, Lacombe L, Harama M: Aromatic Plants of Mali (IV): Chemical Composition of Essential Oils of Cymbopogon citratus (DC) Stapf and C. giganteus (Hochst.) Chiov. J Essent Oil Res 2001, 13:110-112

56. Ketoh GK, Koumaglo HK, Glitho IA: Inhibition of Callosobruchus maculatus (F.) (Coleoptera: Bruchidae) development with essential oil extracted from Cymbopogon schoenanthus L. Spreng. (Poaceae), and the wasp Dinarmus basalis (Rondani) (Hymenoptera: Pteromalidae). J Stored Prod Res 2005, 41:363-371.

57. Koba K, Sanda K, Raynaud C, Nenonene YA, Millet J, Chaumont JP: Activités antimicrobiennes d'huiles essentielles de trois Cymbopogon sp. africains vis-àvis de germes pathogènes d'animaux de compagnie. Ann Med Vet 2004, 148:202-206

58. Ogunwande IA, Olawore NO, Adeleke KA, Konig WA: Chemical composition of the essential oils from the leaves of three Eucalyptus species growing in Nigeria. J Essent Oil Res 2003, 15:297-301.

59. Alitonou G, Avlessi F, Wotto VD, Ahoussi E, Dangou J, Sohounhloué DCK: Composition chimique, propriétés antimicrobiennes et activités sur les tiques de I'huile essentielle d'Eucalyptus tereticornis Sm. C R Chimie 2004, 7:1051-1055.

60. Lucia A, Licastro S, Zerba E, Masuh H: Yield, chemical composition, and bioactivity of essential oils from 12 species of Eucalyptus on Aedes aegypti larvae. Entomol Exp App/ 2008, 129:107-114.

61. Toloza AC, Lucia A, Zerba E, Masuh H, Picollo Ml: Interspecific hybridization of Eucalyptus as a potential tool to improve the bioactivity of essential oils against permethrin-resistant head lice from Argentina. Bioresour Technol 2008, 99:7341-7347.

62. Dagne E, Bisrat D, Alemayehu M, Worku T: Essential oils of twelve Eucalyptus species from Ethiopia. J Essent Oil Res 2000, 12:467-470. 
63. Singh HP, Mittal S, Kaur S, Batish DR, Kohli RK: Characterization and antioxidant activity of essential oils from fresh and decaying leaves of Eucalyptus tereticornis. J Agric Food Chem 2009, 57:6962-6966.

64. Pino JA, Marbot R, Quert R, García H: Study of essential oils of Eucalyptus resinifera Smith, E. tereticornis Smith and Corymbia maculata (Hook.) K. D. Hill \& L. A. S. Johnson, grown in Cuba. Flavour Fragr J 2002, 17:1-4.

65. Benayache S, Benayache F, Benyahia S, Chalchat J-C, Garry R-P: Leaf Oils of some Eucalyptus Species Growing in Algeria. J Essent Oil Res 2001, 13:210-213

66. Benoit-Vical F, Valentin A, Mallié M, Bessière J-M: Antiplasmodial Activity of Cochlospermum planchonii and C. tinctorium Tubercle Essential Oils. J Essent Oil Res 2001, 13:65-67.

67. Ouattara L, Koudou J, Obame LC, Karou DS, Traore A, Bessiere JM: Chemical composition and antibacterial activity of Cochlospermum planchoni Hook.f. ex Planch essential oil from Burkina Faso. Pak J Biol Sci 2007, 10:4177-4179.

68. Alitonou GA, Koudoro AY, Sossou Dangou J, Yehouenou B, Avlessi F, Adeoti S, Menut C, Sohounhloue DCK: Volatile constituents and biological activities of essential oil from Securidaca longepedunculata Fers. growing in Benin. St Cerc St CICBIA 2012, 13:33-42.

69. Adebayo MA, Karioti A, Skaltsa H, Ogunwande IA: Essential Oils of Nigeria II: Analysis of the leaf Oil of Securidaca longependuculata Fers. J Essent Oil Res 2007, 19:452-454.

70. Nébié RHC, Yaméogo RT, Bélanger A, Sib FS: Salicylate de méthyle, constituant unique de l'huile essentielle de l'écorce des racines de Securidaca longepedunculata du Burkina Faso. C R Chimie 2004, 7:1003-1006.

71. Jayasekara TK, Stevenson PC, Belmain SR, Farman DI, Hall DR: Identification of methyl salicylate as the principal volatile component in the methanol extract of root bark of Securidaca longepedunculata Fers. J Mass Spectrom 2002, 37:577-580.

72. Prasad CS, Shukla R, Kumar A, Dubey NK: In vitro and in vivo antifungal activity of essential oils of Cymbopogon martini and Chenopodium ambrosioides and their synergism against dermatophytes. Mycoses 2010, 53:123-129

73. Freitas FP, Freitas SP, Lemos GC, Vieira IJ, Gravina GA, Lemos FJ: Comparative larvicidal activity of essential oils from three medicinal plants against Aedes aegypti L. Chem Biodivers 2010, 7:2801-2807.

74. Oyedele AO, Gbolade AA, Sosan MB, Adewoyin FB, Soyelu OL, Orafidiya OO: Formulation of an effective mosquito-repellent topical product from Lemongrass oil. Phytomedicine 2002, 9:259-262.

75. Hadjiakhoondi A, Vatandoost H, Jamshidi A, Amiri EB: Chemical constituents of efficacy of Cymbopogon Olivieri (Boiss) bar essential oil against malaria vector, Anopheles Stephensi. DARU 2003, 11:125-128

76. Bowers WS, Ortego F, You X, Evans PH: Insect Repellents from the Chinese Prickly Ash Zanthoxylum bungeanum. J Nat Prod 1993, 56:935-938.

77. Abdelgaleil SA, Abbassy MA, Belal AS, Abdel Rasoul MA: Bioactivity of two major constituents isolated from the essential oil of Artemisia judaica $\mathrm{L}$. Bioresour Technol 2008, 99:5947-5950.

78. Clemente MA, de Oliveira Monteiro CM, Scoralik MG, Gomes FT, de Azevedo Prata MC, Daemon E: Acaricidal activity of the essential oils from Eucalyptus citriodora and Cymbopogon nardus on larvae of Amblyomma cajennense (Acari: Ixodidae) and Anocentor nitens (Acari: Ixodidae). Parasitol Res 2010, 107:987-992.

79. Kramer KJ, Beeman RW, Speirs WE, Burkholder WE, McGovern TP: Effects of 2-tridecanone and analogs on the reproduction and mortality of stored product insects. J Kansas Entomol Soc 1985, 58:254-260.

80. Kimps NW, Bissinger BW, Apperson CS, Sonenshine DE, Roe RM: First report of the repellency of 2-tridecanone against ticks. Med Vet Entomol 2011 25:202-208.

81. Massebo F, Tadesse M, Bekele T, Balkew M, Gebre-Michael T: Evaluation on larvicidal effects of essential oils of some local plants against Anopheles arabiensis Patton and Aedes aegypti Linnaeus (Diptera, Culicidae) in Ethiopia. Afr J Biotechnol 2009, 8:4183-4188.

doi:10.1186/1756-3305-6-337

Cite this article as: Bossou et al:: Chemical composition and insecticidal activity of plant essential oils from Benin against Anopheles gambiae (Giles). Parasites \& Vectors 2013 6:337.

\section{Submit your next manuscript to BioMed Central and take full advantage of:}

- Convenient online submission

- Thorough peer review

- No space constraints or color figure charges

- Immediate publication on acceptance

- Inclusion in PubMed, CAS, Scopus and Google Scholar

- Research which is freely available for redistribution 